\title{
POOR SLEEP, ANXIETY AND DEPRESSION AMONG THE MARITIME AND HEALTH SCIENCES HIGHER SCHOOL STUDENTS
}

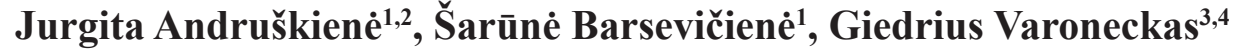 \\ ${ }^{1}$ Klaipeda State University of Applied Sciences, ${ }^{2}$ Klaipeda University, Faculty of Health Sciences, \\ ${ }^{3}$ Klaipeda University, Faculty of Health Sciences, Health Research and Innovation Science Centre, \\ ${ }^{4}$ Klaipeda University Hospital, Sleep Medicine Centre, Lithuania
}

Key words: poor sleep, anxiety, depression, students, age, year of studying.
Summary
Aim of the study was to evaluate the associations among poor sleep, anxiety and depression in re- lation to age and year of studying among the stu- dents.
Methods. The study sample consisted of 400 Klai- peda State University of Applied Sciences students (96.8\% female) and 393 The Lithuanian Maritime Academy students ( $78.9 \%$ male), from 18 to 46 ye- ars of age. Pittsburgh Sleep Quality Index (PSQI) was used for subjective sleep quality evaluation. Hospital Anxiety and Depression (HAD) scale was used to identify depression and anxiety. PSQI score $\leq 5$ was evaluated as good sleep quality; $>5$ - poor sleep. HAD score from 0 to 7 was evaluated as no depression or anxiety, score $>7$ indicated depression and/or anxiety. Additional questions about respon- dents' age, gender, study programme and year of the studying were used. The Chi-square test or Fisher exact tests were used to estimate association betwe- en categorical variables. Student's t test was used to compare means and $\mathrm{z}$ criteria was used to test the difference in two population proportions. Binary lo- gistic regression analysis was performed to evaluate the factors influencing poor sleep.
Results. Health sciences students, as compared to maritime students, had higher prevalence of poor sleep (69.8\% vs $45.0 \%)$ and anxiety $(55.5 \%$ vs $41.7 \%$ ). Depression score was higher among the students with poor sleep, as compared to good sleep, respectively 4.38 vs 3.20 (20 yrs), 5.16 vs 3.29 ( 21 yrs), 5.38 vs 3.22 ( $\geq 22$ yrs). Anxiety score was higher among the students with poor sleep, as

compared to good sleep, respectively 7.89 vs 6.11 (18-19 yrs), 8.73 vs 6.12 (20 yrs), 10.40 vs 6.51 (21 yrs), 10.58 vs 6.40 ( $\geq 22 \mathrm{yrs}$ ). The risk of poor sleep was significantly decreased by the studying marine sciences $(\mathrm{OR}=0.365)$ and increased by anxiety $(\mathrm{OR}=1.172), \mathrm{p}<0.001$.

Conclusions. Poor sleep and anxiety were more prevalent among the students of Health Sciences, as compared to students of Lithuanian Maritime Academy. Anxiety and depression mean scores were significantly higher among the students who had poor sleep, as compared to the ones who had good sleep in all age groups, during the first, second and third year of studies. Risk of poor sleep was increased by anxiety, however maritime studies had positive effect on sleep quality.

\section{Introduction}

The concern about the sleep quality, depression and anxiety among the students of higher schools is constantly increasing, especially among those studying medicine, health sciences and maritime sciences. The results of crosssectional survey, which was conducted among 364 nursing students of the University of L'Aquila, in Italy, demonstrated the overall prevalence of insomnia $26.7 \%$. It increased significantly from $10.3 \%$ for students aged $<20$ years to $45.5 \%$ for those aged $>40$ years. Even $9.4 \%$ of the students had disorders of initiating sleep, $8.3 \%$ had disrupted sleep, $7.7 \%$ - early morning awakenings [1]. More than one third (31\%) of the medical students from University of Tartu, aged 19-33 years, evaluated their sleep quality as satisfactory, poor or very poor [2]. $17.3 \%$ of medical students in India had increased daytime sleepiness [3]. The majority of pharmaceutical students $(>92 \%)$ in Libya reported dissatisfaction with sleep quality and duration [4]. The possible outcomes of sleep loss among the students could be emo- 
tional exhaustion [5] and worsened academic achievements [6]. There is scientific evidence demonstrating worsened judgement ability resulted by 24 hours of sleep deprivation [7]. A systematic review, aiming to examine the prevalence of depression and anxiety among the students of medical schools in the UK, Europe and elsewhere in the Englishspeaking world outside North America, was conducted. Prevalence of 7.7-65.5\% for anxiety, $6.0-66.5 \%$ for depression [8] was assessed. High levels of depression (69.9\%) and anxiety (66.4\%) were indicated at Umm Al-Qura University, Saudi Arabia among medical and dental students. Third-year students were more depressed in comparison with second-year students [9]. Anxiety was also more prevalent among the last year medical students as compared to the first year [10]. The students undertaking internships had higher depression levels as compared to those having preclinical training [11].

The prevalence of anxiety and depression before the beginning of medical training among the students in Malaysia university was $55.6 \%$ and $1.8 \%$, respectively. The prevalence of anxiety during medical training ranged between $41.1 \%$ and $56.7 \%$. The prevalence of depression during medical training ranged between $12 \%$ and $30 \%$. The differences of mean scores of depression before and during medical training were significant $(\mathrm{p}<0.001)$. The prevalence and level of depression during medical training were significantly higher than before the beginning of medical training [12].

There is an evidence to suggest that insufficient sleep and irregular sleep-wake patterns resulting chronic sleep debt are present at alarming levels in the student population, especially studying medicine or health sciences.

The scientific findings indicated that students of Maritime Academy in Gdynia were more vulnerable to stress at ships, related with lack of control, lack of support, unsufficient social relations, as compared to experienced deck officers and ship engineers [13]. Stress at work, resulting depression and/or anxiety, was common complaint reported by women seafarers, and even 55\% said it was related to their working conditions [14]. According to scientific literature, work at sea involved multiple risk factors for fatigue, which in addition to acute effects (e.g., impaired cognition, accidents) contributed through autonomic, immunologic and metabolic pathways to the development of chronic diseases that were particularly prevalent in seafarers [15].

The research in the area of students 'sleep quality and mood disorders is lacking in Lithuania, as well as other European countries. There were no studies in Lithuania analyzing and comparing sleep quality, anxiety and depres- sion between the students, studying health and maritime sciences. We have chosen for this study two institutions of higher education in Klaipeda city. The Faculty of Health Sciences in Klaipeda State University of Health Sciences implements the study programmes of Nursing, Physiotherapy, Dental Hygiene, Dental Assisting, Dietetics, Beauty Therapy and Social Work. The students from all study programmes were involved in this study. Lithuanian Maritime Academy is implementing wide range of study programmes in the area of marine sciences: Marine Navigation, Marine Engineering, Port and Shipping Management, Finances of Port and Shipping Companies and Maritime Transport Logistics Technologies. Students from all study programmes were involved in the study. Klaipeda is a city, located on Baltic Sea coast and is the main port in Lithuania.

The aims of this study were: 1 . To compare the prevalence of poor sleep, depression and anxiety between the students of two higher education institutions - Faculty of Health Sciences in Klaipeda State University of Health Sciences and Lithuanian Maritime Academy; 2. To assess the prevalence of poor sleep, anxiety and depression in relation to age and year of studying; 3 . To assess the factors predisposing poor sleep among the students.

\section{Material and methods}

Study sample. The survey was conducted in March 2014 and March, 2016. The study sample consisted of 400 Klaipeda State University of Applied Sciences students, response rate $86 \%$ (96.8\% were female) and $393 \mathrm{The} \mathrm{Li}-$ thuanian Maritime Academy students, response rate $79 \%$ ( $78.9 \%$ of them males), from 18 to 46 years of age. The first $(36.8 \%)$, the second $(33.0 \%)$, the third $(30.2 \%)$ year students were involved in the study. Mean age of the students was 20.836 ( $\mathrm{SD}=2.632$ ). The grouping was performed according to the age: 18 -19 years $(26.1 \%), 20$ (26.1\%) and 21 years $(26.4 \%)$, and $\geq 22$ years $(21.4 \%)$. Frequency of the subjectively perceived sleep quality, anxiety and depression was compared in gender, age groups, studying year groups and different institution groups.

The study was approved by Bioethics Committee.

Questionnaires. Pittsburgh Sleep Quality Index (PSQI) [16] was used for subjective sleep quality evaluation. PSQI is a self-rated questionnaire which assesses sleep quality over a 1-month time interval. 19 individual items generated seven "component" scores: subjective sleep quality, sleep latency, sleep duration, habitual sleep efficiency, sleep disturbances, use of sleeping medication, and daytime dysfunction. The sum of scores for these seven components yielded one global score, with a range of 0-21 points, " 0 " indicating no difficulty, and " 21 " indicating severe difficul- 


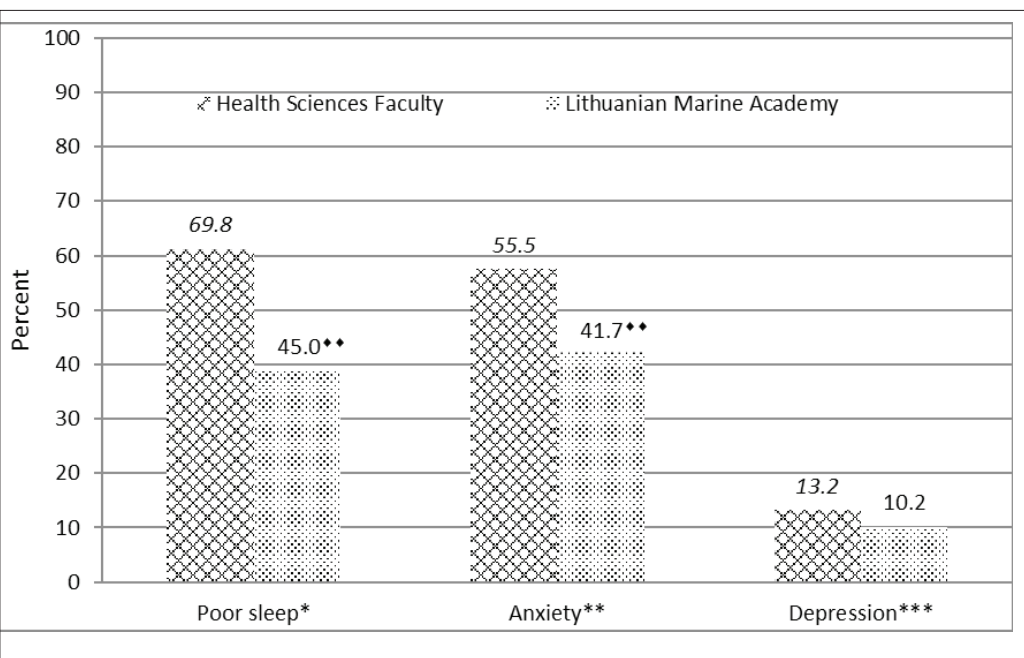

Figure 1. Comparing prevalence of poor sleep, anxiety and depression between the students of the Faculty of Health Sciences and Lithuanian Maritime Academy $\bullet-\mathrm{p}<0.001$, compared to the reference group (Italic)

$*-\chi^{2}=49.538 ; \mathrm{df}=1 ; \mathrm{p}<0.001$

$* *-\chi^{2}=15.045 ; \mathrm{df}=1 ; \mathrm{p}<0.001$

$* * *-\chi^{2}=1.807 ; \mathrm{df}=1 ; \mathrm{p}>0.05$

ties in all areas. PSQI score $\leq 5$ was evaluated as good sleep quality; $>5$ - poor sleep.

Hospital Anxiety and Depression (HAD) scale [17], a self-assessment scale was used to identify the presence of depression and anxiety during the past week. The HAD scale has in total 14 items, with responses being scored on a scale of 0-3, with 3 indicating higher symptom frequencies. Score for each subscale (anxiety and depression) ranged from 0-21 with scores categorized as follows: normal $(0-7)$, disorder $(>7)$. Scores for the entire scale (emotional distress) ranged from $0-42$, with higher scores indicating more distress. Prior to completing the scale respondents were asked to "fill it complete in order to reflect how they have been feeling during the past week" [17].

Table 1. Mean scores of depression and anxiety, according to sleep quality in age groups

${ }^{*} p<0.05$, as compared to the good sleepers as a reference group (italic) $* * p<0.001$, as compared to the good sleepers as a reference group (italic)

\begin{tabular}{|l|l|c|c|}
\hline \multicolumn{2}{|c|}{ Age/sleep quality } & Depression & Anxiety \\
\cline { 3 - 4 } \multicolumn{2}{|c|}{} & Mean; SD & Mean; SD \\
\hline $\begin{array}{l}\mathbf{1 8 - 1 9} \text { yrs } \\
(\mathbf{n}=\mathbf{2 0 7})\end{array}$ & Good sleep $(n=83)$ & $3.11 ; 2.343$ & $6.11 ; 3.835$ \\
\cline { 2 - 4 } & Poor sleep $(\mathrm{n}=124)$ & $3.75 ; 2.593$ & $7.89 ; 3.509 * *$ \\
\hline $\begin{array}{l}\mathbf{2 0} \text { yrs } \\
(\mathbf{n}=\mathbf{2 0 7})\end{array}$ & Good sleep $(n=94)$ & $3.20 ; 2.626$ & $6.12 ; 3.436$ \\
\cline { 2 - 4 } $\begin{array}{l}\mathbf{2 1} \text { yrs } \\
(\mathbf{n}=\mathbf{2 0 9})\end{array}$ & Poor sleep $(\mathrm{n}=113)$ & $4.38 ; 2.801 *$ & $8.73 ; 4.257 * *$ \\
\cline { 2 - 4 } & Good sleep $(n=93)$ & $3.29 ; 2.277$ & $6.51 ; 4.040$ \\
\hline $\begin{array}{l}\mathbf{2 2} \text { yrs } \\
(\mathbf{n}=\mathbf{1 7 0})\end{array}$ & Poor sleep $(\mathrm{n}=116)$ & $5.16 ; 3.281 * *$ & $10.40 ; 4.842 * *$ \\
\cline { 2 - 4 } & Good sleep $(n=67)$ & $3.22 ; 2.479$ & $6.40 ; 3.358$ \\
\hline
\end{tabular}

Additional sociodemographic questions about respondents' age, gender, study programme and year of the studying were included in the questionnaire.

Statistical Analysis. The Chi-square test or Fisher exact tests were used to estimate association between categorical variables. Student's t test was used to compare means and $\mathrm{z}$ criteria was used to test the difference in two population proportions. Binary logistic regression analysis was performed in order to assess factors predisposing poor sleep in students.

Data analysis performed using SPSS 20.0.P-values less than 0.05 were interpreted as statistically significant.

\section{Results}

Poor sleep was more prevalent among the students of the Faculty of Health Sciences $(69.8 \%$, 95\% CI 65.23 74.27), as compared to the students of Lithuanian Maritime Academy (45.0\%, 95\% CI 40.10 - 49.97), $\mathrm{p}<0.001$ (Fig. 1). Anxiety was also more prevalent among the students of Health Sciences, as compared to the students of Lithuanian Maritime Academy, respectively 55.5\% (95\% CI 50.62 60.38 ) vs $41.7 \%$ (95\% CI $36.84-46.62), \mathrm{p}<0.001$.

Depression mean score was significantly higher among 20 years old students having poor sleep (4.38), as compared to good sleeping students (3.20) in the same age group (Table 1). Depression mean score was also higher among older students, 21 year and $\geq 22$ years old who had poor sleep, as compared to those who had good sleep, 5.16 vs 3.29 and 5.38 vs $3.22, p<0.001$.

Anxiety mean score was significantly higher among 18 19 years old students who had poor sleep (7.89), as compared to those who had good sleep (6.11), $\mathrm{p}<0.001$ (Table 1). Axiety score was also higher among 20 years, 21 year and older than 22 years old students, having poor sleep, as compared to those who had good sleep in each age group respectively, 8.73 vs $6.12,10.40$ vs $6.51,10.58$ vs $6.40, p<0.001$.

Depression score was significantly higher among the students who had poor sleep, as compared to those who had good sleep in the first year (4.02 vs 3.19; $\mathrm{p}<0.05)$, second year (4.78 vs $3.16 ; \mathrm{p}<0.001)$ and third year (5.25 vs 3.29 ; $\mathrm{p}<0.001$ ) of studying (Table 2).

Anxiety mean score was also higher among the students who had poor sleep, as compared to those who had good sleep in the first year ( 8.17 vs $5.91 ; \mathrm{p}<0.001)$, second year $(9.19$ vs $6.27, p<0.001)$ and third year $(10.97$ vs 6.72 , $\mathrm{p}<0.001$ ) (Table 2). 
Odds ratios for the prediction of poor sleep among the students were calculated. The risk of poor sleep was significantly decreased by the studying marine sciences $(\mathrm{OR}=0.365)$ and increased by anxiety $(\mathrm{OR}=1.172)$, $\mathrm{p}<0.001$ (Table 3).

\section{Discussion}

The first comparative data about sleep quality, anxiety and depression among the students in health and maritime sciences was obtained. These two study areas were chosen for investigation for the reason that health care workers, as well as seafarers, have very special working conditions, requiring highest concentration, high level of responsibility and coping with shift work $[18,19]$.

Previous studies have reported the effect of occupational factors on sleep quality. The study, conducted by Swedish scientists confirmed that higher work demands predicted disturbed sleep, but shift work did not. On the other hand disturbed sleep predicted subsequent higher work demands, perceived stress, less social support and lower degree of control [20]. Other study reported that shift workers as having an increased risk of falling asleep at work and insomnia [21].

The most interesting finding was that health sciences students had significantly higher prevalence of poor sleep and anxiety, as compared to maritime students. This finding is in line of some studies, confirming medical studies as very stressful, from $20.9-90.0 \%$ of medical students experience stress, 7.7-65.5\% anxiety, 6.0-66.5\% depression [22-24].

Studying maritime sciences also is related with stress, because maritime students during the study process realize that being a seaman require to collaborate with others, to perform complex mental tasks and to support co-workers. They also feel that their future job will involve elements of competition and problems related to interpersonal conflicts, and expect that their work will be performed under hard psychophysical conditions [13].

The main difference between medical/health care and maritime professions is that seafarers must have periodic health check-ups, so "healthy worker" effect can act as confounding factor, when we compare these two professions. Despite this, seafarers experience some specific stressors on ships, such as separation from family, loneliness on board, fatigue, multi-nationality, limited recreation activity and sleep deprivation [25].

The novel aspect in this study was investigating the associations among poor sleep, anxiety and depression in very young age groups, starting from 18 years old. The results of our study demonstrated close relationships among poor sleep, anxiety and depression, in all investigated age
Table 2. Mean scores of depression and anxiety, according to sleep quality in year of studying groups

${ }^{*} p<0.05$, as compared to the good sleepers as a reference group (italic)

${ }^{* *} p<0.001$, as compared to the good sleepers as a reference group (italic)

\begin{tabular}{|c|c|c|c|}
\hline \multirow{2}{*}{\multicolumn{2}{|c|}{$\begin{array}{c}\text { Year of studies/sleep } \\
\text { quality }\end{array}$}} & \multirow{2}{*}{\begin{tabular}{c|} 
Depression \\
Mean; SD \\
\end{tabular}} & \multirow{3}{*}{$\begin{array}{c}\text { Anxiety } \\
\text { Mean; SD } \\
5.91 ; 3.911\end{array}$} \\
\hline & & & \\
\hline \multirow{2}{*}{$\begin{array}{l}\text { First } \\
\text { year } \\
(n=291)\end{array}$} & $\begin{array}{l}\text { Good sleep } \\
(n=117)\end{array}$ & $3.19 ; 2.619$ & \\
\hline & $\begin{array}{l}\text { Poor sleep } \\
(n=174)\end{array}$ & $4.02 ; 2.674 *$ & $8.17 ; 3.982 * *$ \\
\hline \multirow{2}{*}{$\begin{array}{l}\text { Second } \\
\text { year } \\
(n=262)\end{array}$} & $\begin{array}{l}\text { Good sleep } \\
(n=119)\end{array}$ & $3.16 ; 2.182$ & $6.27 ; 3.285$ \\
\hline & $\begin{array}{l}\text { Poor sleep } \\
(n=143)\end{array}$ & $4.78 ; 3.086 * *$ & $9.19 ; 3.972 * *$ \\
\hline \multirow{2}{*}{$\begin{array}{l}\text { Third } \\
\text { year } \\
(n=240)\end{array}$} & $\begin{array}{l}\text { Good sleep } \\
(n=101)\end{array}$ & $3.29 ; 2.483$ & $6.72 ; 3.842$ \\
\hline & $\begin{array}{l}\text { Poor sleep } \\
(n=139)\end{array}$ & $5.25 ; 3.107 * *$ & $10.97 ; 4.681 * *$ \\
\hline
\end{tabular}

Table 3. Factors predicting poor sleep among the students OR=Odds Ratio, $C I$-confidence interval

\begin{tabular}{|l|c|c|c|}
\hline \multirow{2}{*}{ Predictors } & \multicolumn{3}{|c|}{ Poor sleep } \\
\cline { 2 - 4 } & OR & $95 \%$ CI & P \\
\hline Male gender & 0.923 & $0.571-1.494$ & 0.745 \\
\hline Marine studies & 0.365 & $0.228-0.586$ & $<0.001$ \\
\hline Anxiety & 1.172 & $1.113-1.234$ & $<0.001$ \\
\hline Depression & 1.057 & $0.977-1.142$ & 0.165 \\
\hline
\end{tabular}

groups. We have got interesting results that the mean scores of anxiety were significantly higher among those students having poor sleep, as compared with those having good sleep in all age groups, but depression mean scores were higher among poor sleepers only among 20 year old students and older ones. It confirmed the results of other study [26] demonstrating interrelations among stress, anxiety, depression, insomnia, etc.

We aimed to investigate the associations among poor sleep, anxiety and depression in relation to the year of studying. Previous study [19] demonstrated that consequences of stress are mostly observed in the end of studying process when students fully got acquainted with the future profession and fully realized the responsibility in their future job. Our study results showed close associations among poor sleep, anxiety and depression among the first, second and third year students.

The results of our study proved that stress and it's consequences could be monitored and effectively controlled among medical and maritime students during study process, in order to avoid the development of more serious health problems. 


\section{Conclusions}

1. Poor sleep and anxiety were more prevalent among the students of Health Sciences, as compared to students of Lithuanian Maritime Academy.

2. Anxiety and depression mean scores were significantly higher among the students who had poor sleep, as compared to the ones who had good sleep in all age groups, during the first, second and third year of studies.

3. Risk of poor sleep was increased by anxiety, however maritime studies had positive effect on sleep quality.

\section{References}

1. Angelone AM, Mattei A, Sbarbati M, Di Orio F. Prevalence and correlates for self-reported sleep problems among nursing students. J Prev Med Hyg 2011; 52(4):201-208.

2. Veldi M, Aluoja A, Vasar V. Sleep quality and more common sleep-related problems in medical students. Sleep Med 2005; 6(3):269-75.

http://dx.doi.org/10.1016/j.sleep.2004.12.003

3. Giri P1, Baviskar M, Phalke D. Study of sleep habits and sleep problems among medical students of Pravara institute of medical sciences loni, Western maharashtra, India. Ann Med Health Sci Res 2013; 3(1):51-4.

http://dx.doi.org/10.4103/2141-9248.109488

4. Taher YA, Samud AM, Ratimy AH, Seabe AM. Sleep complaints and daytime sleepiness among pharmaceutical students in Tripoli. Libyan J Med 2012; 7.

http://dx.doi.org/10.3402/ljm.v7i0.18930

5. Pagnin D, de Queiroz V, Carvalho YT, Dutra AS, Amaral MB, Queiroz TT. The relation between burnout and sleep disorders in medical students. Acad Psychiatry 2014; 38: 438-444.

http://dx.doi.org/10.1007/s40596-014-0093-z

6. Ahrberg K, Dresler M, Niedermaier S, Steiger A, Genzel L. The interaction between sleep quality and academic performance. J Psychiatr Res 2012; 46: 1618-1622.

http://dx.doi.org/10.1016/j.jpsychires.2012.09.008

7. Dixit A, Thawani R, Goyal A, Vaney N. Psychomotor performance of medical students: effect of 24 hours of sleep deprivation. Indian J Psychol Med 2012; 34: 129-132.

http://dx.doi.org/10.4103/0253-7176.101777

8. Hope V, Henderson M. Medical student depression, anxiety and distress outside North America: a systematic review. Med Educ 2014; 48(10):963-79.

http://dx.doi.org/10.1111/medu.12512

9. Aboalshamat K, Hou XY, Strodl E. Psychological well-being status among medical and dental students in Makkah, Saudi Arabia: a cross-sectional study. Med Teach 2015; 37(1):75-81.

http://dx.doi.org/10.3109/0142159X.2015.1006612

10. Bayram N, Bilgel N. The prevalence and socio-demographic correlations of depression, anxiety and stress among a group of university students. Social Psychiatry and Psychiatric Epi- demiology 2008; 43(8):667-672.

http://dx.doi.org/10.1007/s00127-008-0345-x

11. Dyson R, Renk K. Freshmen adaptation to university life: depressive symptoms, stress, and coping. Journal of Clinical Psychology 2006; 62(10): 1231-1244. http://dx.doi.org/10.1002/jclp.20295

12. Yusoff MS, Abdul Rahim AF, Baba AA, Ismail SB, Mat Pa MN, Esa AR. The impact of medical education on psychological health of students: a cohort study. Psychol Health Med 2013; 18(4):420-30.

http://dx.doi.org/10.1080/13548506.2012.740162

13. Jezewska M, Leszczyńska I, Jaremin B. Work-related stress at sea self estimation by maritime students and officers. Int Marit Health 2006; 57(1-4):66-75.

14. Stannard S, Vaughan C, Swift O, Robinson G, Altaf SA, McGarry A. Women seafarers' health and welfare survey. Int Marit Health 2015; 66(3):123-38.

http://dx.doi.org/10.5603/IMH.2015.0027

15. Jepsen JR, Zhao Z, van Leeuwen WM. Seafarer fatigue: a review of risk factors, consequences for seafarers' health and safety and options for mitigation. Int Marit Health 2015; 66(2):106-17.

http://dx.doi.org/10.5603/IMH.2015.0024

16. Buysse DJ, Reynolds CF, Monk TH, Berman SR, Kupfer DJ. (1989). The Pittsburgh Sleep Quality Index (PSQI): A new instrument for psychiatric research and practice. Psychiatry Research 1989; 28(2):193-213. http://dx.doi.org/10.1016/0165-1781(89)90047-4

17. Zigmond AS, Snaith RP. The hospital anxiety and depression scale. Acta Psychiatr Scand 1983; 67:361-370.

http://dx.doi.org/10.1111/j.1600-0447.1983.tb09716.x

18. Andruškienė J, Kuzmienė A, Martinkènas A, Jurgutis A, Ejlertsson G, Andersson I. Psychosocial work experiences related to health: a study of Lithuanian hospital employees. WORK: A Journal of Prevention, Assessment and Rehabilitation 2015; 53(3):669-77.

http://dx.doi.org/10.3233/WOR-152171

19. Andruskiene J, Barseviciene S, Varoneckas G. Poor sleep, anxiety, depression and other occupational health risks in seafaring population. TransNav: The International Journal on Marine Navigation and Safety of Sea Transportation 2016; 10(1); 19-26.

http://dx.doi.org/10.12716/1001.10.01.01

20. Åkerstedt T, Garefelt J, Richter A. et al. Work and sleep-a prospective study of psychosocial work factors, Physical Work Factors, and Work Scheduling. Sleep 2015; 38(7):1129-1136. http://dx.doi.org/10.5665/sleep.4828

21. Ursin B, Baste V, Moen BE. Sleep duration and sleep-related problems in different occupations in the Hordaland Health Study. Scand J Work Environ Health 2009; 35(3):193-202. http://dx.doi.org/10.5271/sjweh.1325 
22. Fares J, Al Tabosh H, Saadeddin Z, El Mouhayyar C, Aridi H. Stress, burnout and coping strategies in preclinical medical students. North American Journal of Medical Sciences 2016; 8(2):75-81. http://dx.doi.org/10.4103/1947-2714.177299

23. Dyrbye LN, Thomas MR, Shanafelt TD. Systematic review of depression, anxiety, and other indicators of psychological distress among U.S. and Canadian medical students. Acad Med 2006; 81(4):354-73.

http://dx.doi.org/10.1097/00001888-200604000-00009

24. Hope V, Henderson M. Medical student depression, anxiety and distress outside North America: a systematic review. Med Educ 2014; 48(10):963-79.

http://dx.doi.org/10.1111/medu.12512

25. Carotenuto A, Molino I, Fasanaro AM, Amenta F. Psychological stress in seafarers: a review. Int Marit Health 2012; 63(4):188-94.

26. Kingdom SE, Smith AP. Combined effects of work-related stress in Her Majesty's Coastguard (HMCG). Int Marit Health 2012; 63(1):63-70.

\section{BLOGOS KOKYBE்S MIEGAS, NERIMAS IR DEPRESIJA TARP JŪREIVYSTĖS IR SVEIKATOS MOKSLŲ AUKŠTUUJU MOKYKLŲ STUDENTŲ}

J. Andruškienė, Š. Barsevičienė, G. Varoneckas

Raktažodžiai: blogos kokybès miegas, nerimas, depresija, studentai, amžius, kursas.

Santrauka

Tyrimo tikslas: įvertinti studentų blogos kokybės miego, nerimo ir depresijos ryšius, priklausomai nuo amžiaus ir kurso.

Metodai. Tyrimo imtis buvo sudaryta iš 400 Klaipèdos valstybinės kolegijos Sveikatos mokslų fakulteto studentų (96,8\% moterys) ir 393 Lietuvos aukštosios jūreivystès mokyklos studentu (78,9\% vyrai), kurių amžius nuo 18 iki 46 metų. Subjektyviam miego kokybès vertinimui buvo naudojamas Pitsburgo miego kokybès indeksas (PMKI). Nerimui ir depresijai nustatyti buvo naudojama Nerimo ir depresijos (HAD) skalè. PMKI reikšmès $\leq 5$ buvo vertinamos kaip "geras megas", o > 5 - "blogos kokybės miegas". HAD skalès reikšmès nuo 0 iki 7 buvo vertinamos kaip "nèra sutrikimų", o >7 - "pasireiškia depresija/nerimas". Papildomai buvo klausiama apie amžių, studijų programą ir kursą. Statistinei analizei naudoti chi kvadrato, Fišerio testai, Stjudent'o t ir z kriterijai. Siekiant nustatyti veiksnius, lemiančius blogos kokybės miegą, taikytas logistinès regresijos metodas.

Rezultatai. Studijuojantieji sveikatos mokslus dažniau skundèsi blogos kokybės miegu, lyginant su jūreivystės studentais $(69,8 \%$ ir 45,0\%) ir nerimu (55,5\% ir 41,7\%). Depresijos įverčio vidurkis buvo aukštesnis tarp studentų, kurie skundèsi blogos kokybès miegu, lyginant su gerai miegančiais studentais, atitinkamai 4,38 ir 3,20 (20 m.), 5,16 ir 3,29 (21 m.), 5,38 ir 3,22 ( $\geq 22$ m.). Nerimo ịverčio vidurkis buvo didesnis tarp blogai miegančių studentų, lyginant su gerai miegančiais, atitinkamai 7,89 ir 6.11 (18-19 m.), 8,73 ir 6,12 (20 m.), 10,40 ir 6,51 (21 m.), 10,58 ir 6,40 ( $\geq 22$ m.). Blogos kokybès miego riziką mažino studijavimas jūreivystès mokslus ( $\mathrm{S} S=0,365)$, didino - patiriamas nerimas ( $\mathrm{S} S=1,172), \mathrm{p}<0.001$.

Išvados. Blogos kokybès miegu ir nerimu dažniau skundèsi studijuojantys sveikatos mokslus, lyginant su jūreivystès studentais. Nerimo ir depresijos įverčių vidurkiai buvo statistiškai reikšmingai didesni tarp tų studentų, kurie skundèsi bloga miego kokybe, lyginant su tais, kurių miegas buvo geras visose amžiaus grupèse ir visuose kursuose. Patiriamas nerimas didino blogos kokybès miego riziką, kurią mažino jūreivystès mokslų studijavimas.

Adresas susirašinėti: jurgita.andruskiene@gmail.com

Gauta 2016-11-07 